\title{
DEFINING WRONGFUL DISMISSAL: THE ALBERTA SCHISM
}

\author{
DENNIS D. BUCHANAN*
}

\begin{abstract}
The law in Alberta regarding wrongful dismissal is at odds. The source of this schism is the moment of breach when an employee is dismissed with insufficient notice. The "Mandatory Notice" doctrine holds it is at the moment of termination, while the "Contractual Option" doctrine holds that the breach occurs on failure to provide reasonable notice or pay in lieu of notice. While the Mandatory Notice doctrine is considered trite law in other jurisdictions, Alberta has continued to develop case law supporting the Contractual Option. However, the Contractual Option doctrine suffers from several fatal flaws which highlight illogical theoretical and practical results flowing from its application. Therefore, this trend must reverse and Alberta must return to the Mandatory Notice doctrine.
\end{abstract}

\section{TABLE OF CONTENTS}

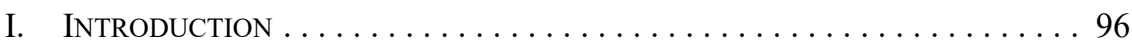

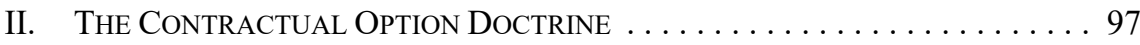

A. PCL Construction Management InC. V. Holmes . . . . . . . . . . 97

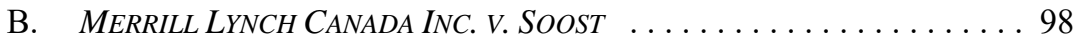

C. STYLES V. ALBERTA INVESTMENT

MANAGEMENT CORPORATION .................... 99

D. CARROLL V. ATCO ELECTRIC LTD. . . . . . . . . . . . . . . . . . . 99

III. Problems in PRinciPle: The DunLop OBJECTIONS $\ldots \ldots \ldots \ldots \ldots \ldots 1$

A. Complexity of IMPled Terms $\ldots \ldots \ldots \ldots \ldots \ldots \ldots \ldots \ldots \ldots$

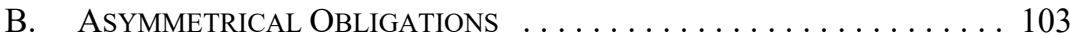

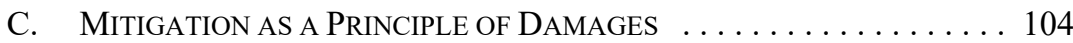

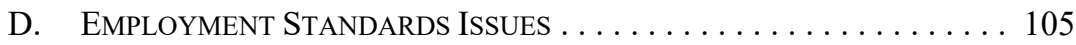

IV. The Mandatory Notice Doctrine $\ldots \ldots \ldots \ldots \ldots \ldots \ldots \ldots \ldots$

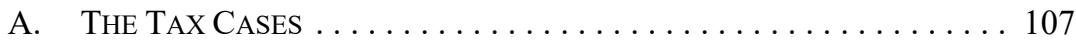

B. Noble V. PRINCIPAL Consultants LtD. (BANKRUPT) . . . . . . . 108

C. DEPUTAT V. EDMONTON SCHOOL DisCTRICT NO. $7 \ldots \ldots$. . . . . 108

D. GLOBEX FoREIGN EXCHANGE CORPORATION V. KELCHER . . . . . . 109

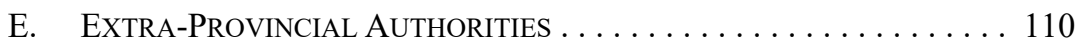

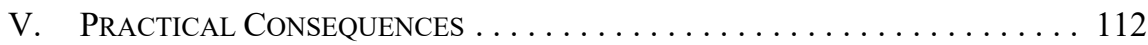

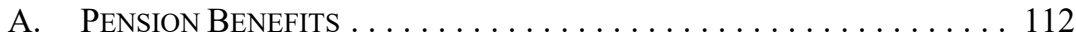

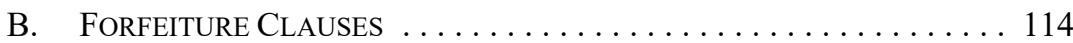

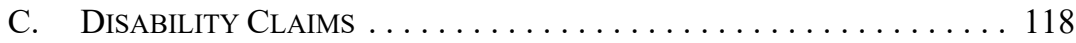

D. ANCILlARY ClAimS AND OVERLAPPING TORTS $\ldots \ldots \ldots \ldots \ldots 119$

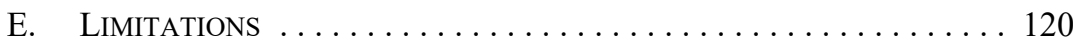

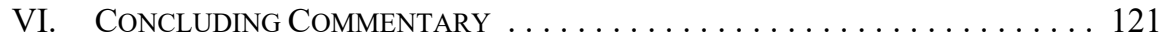

BA (Hons), University of Waterloo; LLB, Queen's University; called to the bar of Ontario in 2009; called to the bar of Alberta in 2018; currently in private practice in Edmonton, Alberta. 


\section{INTRODUCTION}

Wrongful dismissal law largely revolves around an implied term at common law that, unless displaced by express contractual terms, provides for reasonable notice of termination of employment contracts. Under this rubric, vast numbers of dismissed employees pursue and receive money from their former employers, most often referred to as "pay in lieu of notice." 1

In most jurisdictions throughout Canada, the implied term is articulated along these lines. Neither party will terminate the employment relationship without cause, except upon reasonable notice to the other. ${ }^{2}$ Therefore, an employer who terminates an employment relationship without cause and without notice has breached the contract, and "pay in lieu of notice" follows the general rule of damages flowing from the breach of contract. The innocent party is entitled to be put in the same position he or she would have occupied but for the breach, insofar as this can be achieved by the payment of money. ${ }^{3}$

This position has sometimes been adopted by the Alberta Court of Appeal, as in Noble:

In a contract of employment, there is an implied term that each party must give reasonable notice to the other. There is not an implied term that the employer may pay damages in lieu of notice. The employee is entitled to damages because the employer is liable to the employee for breaching the implied term that it must give reasonable notice. The employer cannot characterize such a payment as compliance with an implied term that it can breach the contract so long as it pays because there is no such implied term. ${ }^{4}$

For the purposes of this article, that position will be referred to as the "Mandatory Notice" doctrine or position.

However, there exists another line of current case law in Alberta, arguing that the implied obligation of an employer to provide reasonable notice is tempered with a contractual option to provide pay in lieu of notice and that a termination without notice is not, on its own, a breach of contract, as in Styles v. Alberta Investment Management Corporation: "The common law implies a term of reasonable notice, or pay in lieu, in those circumstances. The payment in lieu is not 'damages' for a breach of the contract, but rather one component of the compensation provided for in the contract. If an employer fails to give proper notice or pay in lieu, the breach is in the failure to pay, not in the termination." ${ }^{5}$ In this article, the

It is also common to see these described as "damages in lieu of notice," "compensation in lieu of notice," or "salary in lieu of notice," though certain characterizations should be used cautiously in employment contracts. "Salary in lieu of notice" is usually an unduly limiting phrase, suggesting that non-salary components of a remuneration package will not be included. In some cases, such language may purport to exclude entitlements to which the employee is entitled by operation of statute, and would be void as a result.

2 See e.g. Ahmad v Procter \& Gamble Inc (1991), 1 OR (3d) 491 (CA); Taylor v Dyer Brown (2004), 73 OR (3d) 358 (CA) [Taylor]; Love v Acuity Investment Managment Inc, 2011 ONCA 130 [Love]; Honda Canada Inc v Keays, 2008 SCC 39 at para 50 [Honda]; Wallace v United Grain Growers Ltd, [1997] 3 SCR 701 at paras 65, 115. Similar articulations have been used in Alberta cases: Hydro Kleen Systems Inc v Park, 2003 ABQB 802; Noble v Principal Consultants Ltd (Bankrupt), 2000 ABCA 133 at para 14 [Noble]; Weber v Capital Industrial Sales \& Service Ltd, 2001 ABPC 125.

3 Hadley $v$ Baxendale, [1854] EWHC Exch J70.

$4 \quad$ Supra note 2 at para 14 [emphasis in original]. See also Deputat v Edmonton School District No 7, 2008 ABCA 13 [Deputat]; Globex Foreign Exchange Corporation v Kelcher, 2011 ABCA 240 [Globex]. 2017 ABCA 1 at para 34 [Styles]. 
position that pay in lieu of notice is a mode of contractual compliance will be referred to as the "Contractual Option" doctrine or position.

These differences have important consequences, both theoretical and practical. The most obvious consequence - different definitions of when a contract has been "breached" — only impacts a narrow range of cases, but the theory underpinning the Contractual Option doctrine has challenging implications.

\section{The Contractual Option Doctrine}

Styles is not the first case in Alberta to articulate termination upon pay in lieu of notice as a contractual option. It follows a number of cases where the Court of Appeal made similar assertions regarding wrongful dismissal principles — whether in a subtle and perhaps accidental articulation of the principles or in an express and deliberate fashion.

\section{A. PCL Construction Management InC. V. Holmes}

In 1994, the case of PCL Construction Management Inc. v. Holmes came before the Alberta Court of Appeal. ${ }^{6}$ Among other issues, the dismissed employee sought a prorated share of dividends in respect of equities held as an employee, for payouts that occurred after the reasonable notice period ended. ${ }^{7}$ In denying his appeal, the Court of Appeal made the following remark: "The employee is entitled only to be placed in the same position as he would have been in had the contract not been breached. The breach of contract consists, not in the dismissal of an employee (for, in the absence of a contract to the contrary, the employer has a right to dismiss), but in the failure to give sufficient notice or sufficient pay in lieu of notice." 8

This articulation of the Contractual Option doctrine appears not to have had an impact on the disposition of the case. While the language describing a breach suggests that providing pay in lieu of notice is a mode of complying with the contract, the Court nonetheless applied the compensation principle on the basis of what would have been received if actual notice had been provided, in a manner consistent with the treatment of pay in lieu of notice, strictly, as damages for breach of contract. ${ }^{9}$

The Court did not apparently turn its mind to the distinction of whether the breach lies in merely the failure to provide notice or the failure to pay. The "or," in that articulation, might be argued to be accidental.

It bears noting that the trial judge did award damages in respect of a dividend payout that was due during the reasonable notice period. This was not appealed, but the Court of Appeal in discussing it appeared to think that the result was appropriate. See ibid at para 17.

$8 \quad$ Ibid at para 26 [emphasis added].

Ibid at paras 27-30. 


\section{B. MERRILL LYNCH CANADA INC. V. SOOST}

Not so in later cases. In the 2010 case of Merrill Lynch Canada Inc. v. Soost, Justice Côté, writing for the Court, was much more deliberate on the point: "I emphasize the word 'or.' No employee has a right to work after dismissal. Every employee can be dismissed at once with no notice and without any grounds. That will not be a breach of the employment contract, provided that the employer gives pay in lieu of notice."10

This case was decided in the wake of the Supreme Court of Canada's revision of the principles of bad faith damages in Honda, and the plaintiff argued that "Honda damages" were necessary to compensate for the stigma of loss of the job. The Court of Appeal concluded that the "loss of the job" was not compensable, because the employer has a contractual right to terminate employment. ${ }^{11}$

This finding does not, at its core, turn on the distinctions between the Mandatory Notice and Contractual Option doctrines. The dismissal of an employee, simpliciter, is not a compensable wrong, regardless of whether one believes that an employer has the contractual right to dismiss now or the contractual right to dismiss later.

And yet, even in Merrill Lynch, the Court's language is mixed: "The wrong was lack of reasonable notice. Damages must be for lack of reasonable notice (which was compensated here and not appealed)... Or for unduly unfair or insensitive manner of dismissal." ${ }^{, 2}$ It is surprising that the Court would use this language accidentally, given that early in the decision it is critical of the terminology of wrongful dismissal:

\footnotetext{
Under such contracts, the common terminology is sloppy, even misleading. We speak of "wrongful dismissal," or damages for that. But there is no such thing there as wrongful dismissal (apart from federal legislation). Under such a contract, either side may validly end the contract at any time. The employee neither has tenure, nor is indentured. The employee and the employer both have the right to end the contract, and ending it is not a breach of contract, nor a tort. ${ }^{13}$
}

As well, discussion of the scale of compensation for lost earnings is limited, because that was not an issue on the appeal, but the Court seems to apply the compensation principle to pay in lieu of notice, characterizing the compensation for lost earnings as being "for lack of a year's notice." 14

$10 \quad 2010$ ABCA 251 at para 13 [Merrill Lynch].

Ibid at paras 9,25 .

Ibid at para 29 [citations omitted] [emphasis added]. It bears noting that, in this passage, the Court referred to the then-recent decision in Jean $v$ Pêcheries Roger L Ltée, 2010 NBCA 10, and specifically to paragraph 55 thereof. The New Brunswick Court of Appeal expressly articulated the Mandatory Notice doctrine and expressly set out that pay in lieu of notice was to be calculated on the basis of "damages" principles.

13 Merrill Lynch, ibid at para 9. The characterization of a dismissal as "wrongful" is generally based on an allegation that the employer lacked just cause and did not provide appropriate notice - - which, under the Mandatory Notice doctrine, is a breach of contract. Furthermore, the Federal statute to which the Court parenthetically alludes here, the Canada Labour Code, RSC 1985, c L-2, ss 240-46, does not speak of "wrongful" dismissal, but "unjust" dismissal, which is a unique creature of statute. Merrill Lynch, ibid at para 27. 
Altogether, however, this decision is express and deliberate on the point. Pay in lieu of notice is a contractual option upon the employer, not in the nature of damages for breach of contract.

\section{STYLES V. ALBERTA INVESTMENT MANAGEMENT CORPORATION}

The Styles decision is relatively recent, dealing with a frequently litigated issue as to whether the plaintiff was entitled to bonuses under a Long Term Incentive Plan (LTIP) as part of his pay in lieu of notice. His dismissal without cause had the effect, as the Court of Appeal found, of terminating his unvested equity interests, in accordance with the language of the LTIP Participation Agreement.

Importantly, there was a written employment agreement in place which provided that his employment could be terminated on the basis of a fixed amount of notice or base salary in lieu of notice. ${ }^{15}$ This was in addition to express language in the Participation Agreement that required active employment for the payout of benefits and that allowed for the forfeiting of entitlements upon termination of employment.

The employment agreement's language, if effective and enforceable (which was not in issue in the litigation), displaces the common law implied term of reasonable notice. Thus, the Court of Appeal's commentary on the nature of the common law implied terms is likely to be obiter. The Court of Appeal grounded its conclusion — denying the plaintiff recovery of any amounts under the LTIP — as flowing from express language of agreements between the parties. ${ }^{16}$

Obiter or not, however, the Court of Appeal was express in asserting that the common law term includes a contractual option to terminate on pay in lieu of notice, even acknowledging in a footnote that " $[\mathrm{t}]$ here are decisions from other jurisdictions that treat termination as a breach, but they do not reflect the law of Alberta."

\section{CARROLL V. ATCO ELECTRIC LTD.}

The most recent decision from the Alberta Court of Appeal in this regard is the Carroll v. ATCO Electric Ltd. decision. ${ }^{18}$ This is another case where the plaintiff was seeking compensation under equity-based compensation plans through the reasonable notice period and where the Court was satisfied that this possibility was precluded by the express language of the agreements between the parties. 
As such, the full significance of the Court's distinction between "damages" and "pay in lieu," in the context of this case, is less than clear:

Furthermore, as pointed out in Styles v Alberta Investment Management Corporation, 2017 ABCA 1 at paras 33 to 34, 44 Alta LR (6th) 214, leave denied [2017] SCCA No 76 (QL) (SCC No 37465), the calculation of reasonable notice is not calculation of damages for breach of contract. It is a calculation of compensation for what the employment contract entitled the employee to receive if his employment was terminated without cause. As such, "[t] he common law implies a term of reasonable notice, or pay in lieu": Styles at para $34 .{ }^{19}$

Indeed, immediately after highlighting the distinction, the Court expressly minimized the importance of the distinction while frankly acknowledging that the Supreme Court of Canada itself has used the term "damages" to describe pay in lieu of notice:

\begin{abstract}
We pause to observe that the possible difference between that language in Wallace using the word "damages" although coupled with the comment "in reality the wages the employer ought to have paid" as compared to the language and approach taken by this Court in Styles as to "compensation" raises the possibility of issues not debated by counsel on this appeal. We note that in the preceding para 65 of Wallace, the Court said "[i]n the absence of just cause, an employer remains free to dismiss an employee at any time provided that reasonable notice of the termination is given." We do not need to tarry on such semantical matters. We also note that any such linguistic difference would not have eluded the Supreme Court in denying leave to appeal in Styles. It is highly unlikely. Consequently, any degree of daylight between ["damages"] is in reality the "wages" and "compensation" need not trouble us here. ${ }^{20}$
\end{abstract}

Given that the Supreme Court of Canada's decisions on leave are delivered without reasons, one might query whether it is reasonable to interpret a refusal to grant leave as an endorsement of a particular proposition of law. ${ }^{21}$ Yet the acknowledgement that the Contractual Option doctrine is not merely inconsistent with the law in other provinces, but inconsistent with the terminology used by the Supreme Court, coupled with the acknowledgement of "the possibility of issues not debated by counsel" suggests a waning confidence in the correctness of the doctrine itself. ${ }^{22}$

By contrast, when declining to follow the Ontario precedents, the Court of Appeal in Styles took the position that the Supreme Court of Canada had confirmed "that it is the non-

Indeed, given the range of decisions of courts around the country on issues surrounding equity-based entitlements through the reasonable notice period, it is very likely that the Supreme Court of Canada will weigh in on the question at some point - but given the express contractual terms in Styles in both the employment agreement and LTIP Participation Agreement, that case may not be an ideal context in which to clarify the law. Note that the Nova Scotia case of Ocean Nutrition Canada Ltd v Matthews, 2018 NSCA 44, has been granted leave by the Supreme Court of Canada and is - as of the most recent revision of this article - scheduled to be heard in October 2019. While the Nova Scotia Court of Appeal followed Styles, one of the issues raised by Mr. Matthews in his successful application for leave is that the conflicting case law around the country on this issue calls for clarification. 
payment that is the breach, not the termination itself," ${ }^{23}$ referencing paragraph 15 of Sylvester v. British Columbia. ${ }^{24}$ That is not an accurate description of the Supreme Court's language:

Damages for wrongful dismissal are designed to compensate the employee for the breach by the employer of the implied term in the employment contract to provide reasonable notice of termination. As discussed above, the damages are assessed by calculating the salary the employee would have received had he or she worked during the notice period, notwithstanding that the employee may, in fact, have been prevented from doing so. The damages are based on the premise that the employee would have worked during the notice period. $^{25}$

Indeed, the Supreme Court, in Sylvester, was even more express on the point in the opening paragraph of the decision: "An employee who is wrongfully dismissed without reasonable notice of termination is entitled to damages for breach of contract." 26

In other words, the Court of Appeal is correct to reject the proposition that the "termination itself" is a breach of contract. However, on the plain language used by the Supreme Court, it is the failure to provide reasonable notice, and not the "non-payment," that constitutes the breach.

\section{Problems in Principle: THE DUNLOP OBJECTIONS}

In its 1988 decision in Dunlop v. B.C. Hydro \& Power Authority, the British Columbia Court of Appeal clarified the nature of pay in lieu of notice:

The implied term is a term to the effect that each party must give reasonable notice of termination to the other. The implied term is not a term to the effect that the employer may give pay in lieu of notice. There are a number of reasons why the latter term is not implied from the employment relationship as part of the contract of employment. It would be a more complicated term than can readily be implied by following the business efficacy and officious bystander rules. It would not operate in the same way with respect to the employee as it would with respect to the employer. It would mean that if an employer elected to give pay in lieu of notice, the employer would be complying with the contract and not breaking it. And the contract would require the full payment to be made immediately. The true nature of the implied term, namely, as being a term that each party must give the other reasonable notice of termination, is indicated by the customary application of the principle of mitigation. If the implied term were to be considered to contain a provision for pay in lieu of notice, and if the employer elected to invoke that term and gave no notice of termination, there would be no obligation on the part of the employee to mitigate damages by seeking other employment, even if the employer did not pay the full amount that such a term would have required, because such a term would require immediate payment of the full amount without regard to the measurement of any loss actually suffered by the employee. But the principle of mitigation is consistently applied, even where the employer elects to make a payment in lieu of notice. The reason is that, when an employer gives pay in lieu of notice, he does

Supra note 5 at para $34, \mathrm{n} 1$.

[1997] 2 SCR 315 [Sylvester].

Ibid at para 15 [emphasis added].

Ibid at para 1 . 
so as an attempt to compensate for his breach of the contract of employment, not as an attempt to comply with an implied term of the contract of employment. ${ }^{27}$

This principled and thorough passage illustrates three fundamental problems with the Contractual Option doctrine. The term is too complex to be readily implied by law; such a term would impose asymmetrical obligations upon the parties; and breach of such a term could not be subject to mitigation under the law of damages.

In addition to these particular problems, there is a further issue in that a contractual amount owing would usually fall into the definition of "wages" under most employment standards statutes, yet the established practice in most regimes does not regard common law pay in lieu of notice as an available remedy under employment standards processes.

\section{A. COMPLEXITY OF IMPLIED TERMS}

The first Dunlop objection is somewhat undermined by its articulation (referencing the business efficacy and officious bystander rules), in light of later clarifications of the law. Per the concurring reasons of Justice McLachlin (as she then was) in Machtinger v. HOJ Industries Ltd., the implied term at issue here is one that arises not from the business efficacy and officious bystander rules, but — quoting Canadian Pacific Hotels Ltd. v. Bank of Montreal — "as legal incidents of a particular class or kind of contract, the nature and content of which have to be largely determined by implication." 28 This proposition has been favourably endorsed by various appellate courts. ${ }^{29}$

Yet the matter of complexity stands nonetheless. The test for contractual terms implied as legal incidents of particular kinds of contract also includes a component of necessity, which precludes the inclusion of superfluous and unnecessary terms. Justice McLachlin went on to quote Lord Wilberforce, from Liverpool City Council v. Irwin, in stating that the test for such an implied term "should be read into the contract as the nature of the contract implicitly requires, no more, no less: a test, in other words, of necessity." ${ }^{30}$

Without a doubt, where the express terms of an employment contract are silent as to its termination, it is necessary to imply a mechanism by which either party may terminate the contract. The necessity of implying more than one mechanism, however - that is, notice or pay in lieu - is more difficult to rationalize. Moreover, if one regards "pay in lieu of notice" as an implied term within the employment contract itself, the next question is the basis on which the quantum of pay in lieu of notice is calculated. Is it salary only? Does it include bonuses? Equity-based incentives? Overtime? Extended health benefits?

Treating pay in lieu as "damages" provides us with a firm and well-established framework for determining the answers to these questions, in the form of the general rule of damages. 
The compensation principle may be complex in its operation in some of these instances, but it provides a sound justification for quantifying damages in a particular manner.

Indeed, the case law supporting the Contractual Option doctrine provides little guidance in terms of the principles upon which to calculate contractual pay in lieu of notice, and the courts appear to largely apply reasoning similar or identical to a "damages" analysis.

\section{B. ASYMmetrical Obligations}

An employee, too, owes reasonable notice of termination to an employer, pursuant to an implied contractual term at common law.

See, for example, the cases of RBC Dominion Securities Inc. v. Merrill Lynch Canada Inc. ${ }^{31}$ or Tree Savers International Ltd. v. Savoy. ${ }^{32}$ In both of these cases, employees were found to have breached their contractual obligations by resigning without providing reasonable notice. Importantly, both of these cases also involve economic tort claims against a third-party employer. Employees departed without much notice and joined a competitor, and the new employer was held liable for damages on the basis of economic torts.

Outside of cases where employees go on to immediately compete with their old employer, it is rare for an employer to pursue wrongful resignation damages — for instance, seeking to recover expenses associated with needing to re-staff a position on an emergency basis (overtime expenses, temp agency fees, and so on), loss of revenues that an employee would have earned over the notice period, or even loss of market share to unrelated third parties flowing from the inability to transition projects or clients. Essentially, the employee's obligation to provide notice has been used primarily as a substitute for restrictive covenants and as a mechanism for making competitors liable for poaching employees who are not subject to restrictive covenants.

For employees obligated to provide notice, there is no conceivable implied contractual option in lieu of providing actual notice of resignation.

The result is that the Contractual Option doctrine implies a term that entitles one party, but not the other, to terminate the contract without any notice whatsoever. Likewise, it is a tort for a third party to induce an employee to terminate the contract without notice, but it would not be a tort to induce an employer to do the same. In a framework that recognizes a power imbalance that typically favours the employer, it is incongruous with the jurisprudence to suggest asymmetrical implied obligations that are less onerous on the employer than upon the employee.

This counterintuitive result is further emphasized by the root cause of the disparity. Employees, as the payee in the relationship, suffer pecuniary losses almost automatically by virtue of termination without notice. Employers, as the payor, will not necessarily suffer any pecuniary losses as a result of a resignation without notice. The implication of the 
Contractual Option is that employees, at least theoretically, are limited to claiming pay in lieu and cannot recover for other damages flowing from the termination without notice. Employers, on the other hand, will be entitled to recover their full provable losses flowing from a resignation without notice.

\section{Mitigation as a Principle of Damages}

If an employer had the contractual option of terminating on notice or pay in lieu thereof, the payment owing upon termination of employment without notice would be in the nature of a liquidated debt, which is not subject to the duty to mitigate.

The obligation to mitigate is triggered by a breach of contract and requires a plaintiff to take reasonable steps to reduce or avoid losses that flow from the breach. ${ }^{33}$ In a scenario where an employer were to dismiss without notice but provide pay in lieu of notice instead, the Contractual Option doctrine would regard this employer as having complied with the implied terms at common law. With no breach of contract, no obligation to mitigate applies, and the employee is under no obligation to account for mitigation earnings. In other words, if the employee goes out and obtains new employment during the reasonable notice period, this could have no impact on his entitlements to contractual pay in lieu of notice.

More significantly, even in a case where an employee is dismissed without notice or pay in lieu, a similar analysis applies. The employee's opportunity to secure alternate employment during the reasonable notice period flows from the termination without notice. Income that could have been earned by the plaintiff regardless of the breach is not to be deducted as mitigation earnings. ${ }^{34}$ If the breach of contract lies not in the termination without notice, but in a separate and subsequent failure to provide "pay in lieu," then the ability to earn additional employment income flows not from that failure to pay, but from the employer's exercise of its contractual option to not provide actual notice. As such, there could never be a case in which "mitigation earnings" could reduce damages in a wrongful dismissal case. ${ }^{35}$

The British Columbia Court of Appeal's commentary in Dunlop is not hypothetical. Employment agreements that expressly preserve an option for the employer to terminate the contract without notice, and instead upon a payment calculated in accordance with a given formula, have become commonplace, and appellate courts from multiple jurisdictions, including Alberta, have interpreted these provisions in the manner suggested by Dunlop. ${ }^{36}$

33 See e.g. Red Deer College v Michaels, [1976] 2 SCR 324 [Red Deer].

$34 \quad$ See Karas v Rowlett (1943), [1944] SCR 1; McIntosh v Saskatchewan Water Corp (1989), 77 Sask R 81 (CA).

35 For absolute clarity, this article should not be taken as suggesting that the state of the law in Alberta is that wrongfully dismissed employees seeking wrongful dismissal damages are not obligated to mitigate their losses or account for mitigation earnings. The argument herein, and in Dunlop, is in the nature of a modus tollens. If "pay in lieu" were part of the implied contractual term, dismissed employees would have no obligation to mitigate. Dismissed employees usually have an obligation to mitigate. Therefore, "pay in lieu" cannot be part of the implied contractual term.

$36 \quad$ See Mills v Alberta, 1986 ABCA 162; Bowes v Goss Power Products Ltd, 2012 ONCA 425 [Bowes]; Allen v Ainsworth Lumber Co Ltd, 2013 BCCA 271; Baim v North Country Catering Ltd, 2017 ABCA 206. 
Increasingly, the trend in the jurisprudence favours treating contractual pay in lieu of notice - as distinct from damages for the failure to provide common law notice - as being exempt from any requirement to mitigate, and this trend is broadly consistent with the first principles of contract law. In light of this framework, the only way to save the Contractual Option doctrine would be to read a quasi-mitigation obligation into the implied term at common law. Once again, this runs into problems of complexity. All the nuance that has developed in the law of damages over the ages - the content and scope of the duty to mitigate, what event triggers the duty to mitigate, the burden of proof, ${ }^{37}$ what earnings constitute mitigation earnings, the duty to account, and so on - would have to be read into this implied term. ${ }^{38}$

\section{EMPLOYMENT STANDARDS ISSUES}

In addition to the concerns raised in Dunlop itself, there is a fourth fundamental inconsistency between the existing wrongful dismissal case law and an implied contractual option to provide pay in lieu of notice. If the implied term creates an obligation upon the employer to provide a certain sum of money, this sum is likely captured within various employment standards frameworks.

Employment standards statutes across the country create frameworks of minimum entitlements to termination pay, pay in lieu of notice, severance pay, and so on. These amounts are payable in short order after the termination, governed by timeframes set out within those statutes. It is an offence not to satisfy those obligations, and employees can seek those entitlements via administrative tribunal processes.

However, in most cases, these administrative tribunal processes are limited to awarding the statutory minimum amounts owing, and an award in respect of common law pay in lieu of notice is outside the scope of the authority of these tribunals.$^{39}$ In certain provinces, such as Nova Scotia, a claim for the statutory minimums can be made through the administrative process, and a subsequent or parallel action can be brought for common law damages. ${ }^{40} \mathrm{In}$ other provinces, such as Ontario, the employment standards statute includes a bar on such parallel proceedings. An employee must elect to either pursue statutory termination and severance pay through the administrative process or seek damages through a court action. ${ }^{41}$

Onus is a particularly challenging aspect of any attempt to reconcile the existing mitigation case law with the notion of a contractual obligation to mitigate. A contractual entitlement subject to a quasimitigation obligation would put the onus on the plaintiff to prove that the condition precedent is satisfied. On the contrary, in the law of damages, the onus to prove failure to mitigate lies upon the defendant, as in Red Deer.

38 The problems of complexity cannot be overstated. Since Bowes, lawyers throughout Ontario and beyond have sought to integrate a contractual mitigation obligation into written employment agreements. It is not an easy task to create, at the outset of the employment relationship, meaningful mechanisms to require the employee to take appropriate steps to find replacement employment, in such a way that complies with employment standards legislation. While the jurisprudence on such contract language is in its infancy, the complexity of the language is likely to open up a wide range of challenges.

39 There are express exceptions to this proposition, such as, for example, under the Canada Labour Code, supra note 13.

$40 \quad$ Deagle $v$ Shean Co-Operative Ltd (1995), 143 NSR (2d) 261 (SC).

41 Galea v Wal-Mart Canada Inc, 2003 CanLII 40536 (Ont SC). 
This status quo has its critics. David Doorey has argued that the expansive definition of wages in Ontario's Employment Standards Act, 2000, being "remuneration payable by an employer to an employee under the terms of an employment contract," 42 captures common law pay in lieu of notice, thus requiring the employer to provide the full common law amount as a matter of statutory compliance. ${ }^{43}$

Under the Mandatory Notice doctrine - which is certainly the state of the law in Ontario - the most straightforward rebuttal to Doorey's argument is that pay in lieu of notice is simply not "remuneration payable... under the terms of an employment contract," but rather damages for the failure of the employer to perform a non-monetary obligation (namely, giving notice of termination). The defining legal proposition of the Contractual Option doctrine, however, would certainly include that pay in lieu of notice is "remuneration payable... under the terms of an employment contract" and therefore Doorey's conclusion would be plainly correct, undermining the entire body of case law on the issue across multiple jurisdictions. ${ }^{44}$

\section{The Mandatory Notice Doctrine}

The implied term of reasonable notice is one of the oldest standing propositions of Canadian common law, having evolved out of the English law of master and servant. Consider the Ontario Court of Appeal's summary of the law in Pollard v. Gibson:

\footnotetext{
The cases of Harnwell v. Parry Sound Lumber Co. (1897), 24 A.R. 110; Bain v. Anderson (1898), 28 Can. S.C.R. 481, and Parker v. Beeching, [1923] 4 D.L.R. 35, seem to me to establish that, in the absence of an express provision to the contrary, or evidence of some usage that every one must be considered to know and to contract with reference to, a contract of general, indefinite, or yearly hiring and service may be terminated on reasonable notice, and that there is no law requiring the notice to end with a year. ${ }^{45}$
}

The controversy as to the precise nature of pay in lieu of notice, however, is much more recent. Prior to discussion of the issue in Dunlop, courts seldom directly addressed the question of whether pay in lieu of notice was a form of damages or merely a mode of completion of the implied contractual term. However, there was a line of cases dealing with the characterization of wrongful dismissal damages for tax purposes.

$42 \quad$ SO 2000, c 41, s 1 [ESA]

43 David Doorey, "Q\&A: Can Employees Recover Reasonable Notice Damages By Filing ESA Complaint?" (24 January 2012), online (blog): Law of Work <lawofwork.ca/?p=4470>.

$44 \quad$ Not all jurisdictions define wages in precisely the same way. In the Alberta Employment Standards Code, RSA 2000, c E-9 [Standards Code], statutory termination pay is excluded from the definition of wages. However, if one regards contractual pay in lieu of notice as supplanting "termination pay," per the "greater benefits" language at section 3, then common law notice would be required to be paid under the "termination pay" framework. If one did not regard contractual pay in lieu of notice as supplanting termination pay, then it would almost certainly fall into the general description of wages at section $1(1)(x)$, as including "salary, pay, money paid for time off instead of overtime pay, commission or remuneration for work, however calculated."

45 (1924), 55 OLR 424 (CA) at 428. See also the reasons of Justice Idington in Allcroft v Adams, [1907] 38 SCR 365 at 374, when rejecting the contention that the language of an employment contract created a fixed term: "It is exceeding doubtful, if this with what the correspondence suggests as possible purpose of the parties, where they have not stated anything definite can within the later authorities be held more than a general hiring, requiring reasonable notice before dismissal, unless for cause." 


\title{
A. The Tax Cases
}

Up until 1978, "damages" for breach of contract were not regarded as taxable income at all. ${ }^{46}$ This had a significant impact on wrongful dismissal litigation.

The Queen v. Atkins was a brief yet influential decision by the Federal Court of Appeal in 1976, where the government sought to tax a post-termination settlement, arguing that the amounts were in the nature of wages and thus taxable. ${ }^{47}$ The Court rejected this position, explaining the "basic fallacy" of the government's position:

\begin{abstract}
Moneys so paid (i.e., "in lieu of notice of dismissal") are paid in respect of the "breach" of the contract of employment and are not paid as a benefit under the contract or in respect of the relationship that existed under the contract before that relationship was wrongfully terminated. The situation is not altered by the fact that such a payment is frequently referred to as so many months' "salary" in lieu of notice. Damages for breach of contract do not become "salary" because they are measured by reference to the salary that would have been payable if the relationship had not been terminated or because they are colloquially called "salary."48
\end{abstract}

While the Supreme Court twice subsequently expressed obiter doubts about the correctness of Atkins, these doubts were focused on whether they were subject to taxation despite being in the nature of damages, suggesting that there may have been a failure to consider whether or not the income may have been taxable under some provision other than as employment income. ${ }^{49}$

\section{As Justice Pigeon highlighted:}

The basic principle governing the award of damages for breach of contract is that "the party complaining should, so far as it can be done by money, be placed in the same position as he would have been in if the contract had been performed". I fail to see any reason why this would not hold true towards the tax collector as well as towards the parties to the contract. ${ }^{50}$

Parliament corrected this by implementing taxation of "retiring allowances" in the Income Tax Act, though not through the same processes as wages or salary. ${ }^{51}$ Amounts paid on retirement in recognition for a long period of service, or "damages" in respect of the loss of employment, are eligible for more favourable treatments. ${ }^{52}$ Tax withholding is usually at a more favourable rate; no withholding is required for CPP or EI, and these amounts may be eligible to be paid directly into an RRSP without any withholding of taxes.

However, amounts in lieu of notice, paid pursuant to a contract of employment, are regarded as wages and are subject to the ordinary rules of withholding. ${ }^{53}$

Schwartz v Canada, [1996] 1 SCR 254 at para 22 [Schwartz].

(1976), 68 DLR (3d) 187 (FCA) [Atkins].

Ibid at $188-89$.

See Jack Cewe Ltd v Jorgenson, [1980] 1 SCR 812 [Jack Cewe]; Schwartz, supra note 46.

Jack Cewe, ibid at 815.

RSC 1985, c 1 (5th Supp), s 56(1)(a)(ii).

See definition of "retiring allowance," ibid, s 248(1).

Ibid, s 6(3). 
As such, the distinction drawn by the Federal Court in Atkins is still an important component of contemporary employment law for tax purposes, and it is squarely rooted in the Mandatory Notice doctrine.

It was not until much later that the courts began to regularly consider this distinction outside of the tax context.

\section{B. Noble V. PRincipal Consultants Ltd. (BANKRUPT)}

Noble involved an employment relationship governed by a written contract including termination language guaranteeing the employee 18 months' notice or pay in lieu. The employer made an assignment in bankruptcy shortly after the termination, however, and the trustee argued that, because the bankruptcy would have had the effect of ending the employment relationship in any event, the plaintiff's damages stopped accruing at that date.

The majority of the Court of Appeal looked to Dunlop, and, as noted above, asserted directly and emphatically that pay in lieu of notice is "not an implied term" of the contract. ${ }^{54}$ As the breach of contract occurred in the failure to give notice, the employee was immediately entitled to the full quantum of damages, which became a valid claim in the bankruptcy proceedings.

\section{DEPUTAT V. EDMONTON SCHOOL DistRICT No. 7}

As in the case of Merrill Lynch, above, the reasons in Deputat were authored by Justice Côté for a unanimous Court. Unlike Merrill Lynch, where the Court expressly asserted that a termination could not amount to a breach of contract if sufficient pay in lieu of notice was provided, the Court in Deputat found the opposite: "[a]n employer is entitled to dismiss any employee without cause. The employer's only duty is to give reasonable notice before doing so. The employer has no duty to pay extra money if it gives enough notice. Pay in lieu of notice is merely damages for breach of contract." 55

The Court went on to make a simple yet critical observation: "NNotice' is just information that the employment will end on a certain date. In the meantime, the employment continues. Notice does not equate to money." 56

The fact pattern in Deputat involved an employee who was dismissed on 12 months' working notice. Among other issues before the Court (including that he sought and obtained a longer notice period), the plaintiff sought additional compensation in respect of accrued vacation entitlements that the employer required him to use during the period of working notice. In this context, the Court of Appeal undertook a careful first principles analysis to

\footnotetext{
$54 \quad$ Noble, supra note 2 at para 14 [emphasis omitted]. It bears noting that the dissenting opinion of Justice Berger also held, at para 49, that "[p] ayment of salary or wages in lieu of notice is not an implied term." 55 Deputat, supra note 4 at para 8.

$56 \quad$ Ibid at para 9.
} 
conclude that there was no basis why a paid vacation could not form part of a working notice period and, accordingly, the plaintiff's claim failed in this regard..$^{57}$

As well, the Court of Appeal reduced his award of pay in lieu of notice on the basis of a failure to mitigate, as he waited until five months before the end of the actual notice period before beginning his job search, on the premise that he was only trying to replace the job after expiration of the actual notice period.

The assumption in the [trial] Reasons is that the respondent had no duty to look for a new job which would start before the old one finished. That is not the law. Mitigation need not be perfect, and there is more than one way to reduce a loss. A new permanent job would be better than the old job which was certain to end inside a year. Indeed, a new job might have better pay or working conditions than the old one. The respondent had a duty to look for a new job, even if a good one might have to be started before the 12 months were up. ${ }^{58}$

This result is a striking example of a conclusion that would likely have been different if the nature of pay in lieu of notice were treated differently. If the breach is the "failure to pay," then the contract was not yet breached during the working notice period, and it is impossible to conclude that any obligation to mitigate had manifested. The only justification otherwise would be in the event of an express indication in the termination letter that no further benefits would be provided following the end of the working notice period, which would raise the possibility of an obligation to mitigate by way of the anticipatory breach doctrine. There is no indication of such an analysis in either the trial or appellate decisions.

\section{GLOBEX FoREIGN EXCHANGE CORPORATION V. KELCHER}

The decision in Globex is somewhat ambiguous on the nature of pay in lieu of notice, despite the fact that the case in large part turns on the nature of the breach in a wrongful dismissal case.

The employer dismissed one employee, Mr. MacLean, without cause and without notice. Subsequently, two other employees - Mr. Kelcher and Mr. Oliverio — resigned and joined him in a competing venture. The employer brought an action and sought an injunction to enforce restrictive covenants which all three employees had signed. Kelcher and Oliverio signed the covenants after the start of their employment, with no fresh consideration, which the Court concluded voided the covenants. MacLean, however, had signed the covenants at the start of his employment, so a critical question on the appeal was the impact of the wrongful dismissal on his obligations under the contract.

Paraphrasing the General Billposting Co. Ltd. v. Atkinson ${ }^{59}$ case from over a century ago, the majority noted that "[w]hen an employee is dismissed without cause or notice, the employer cannot enforce a restrictive covenant otherwise binding the employee." ${ }^{60}$ With some discussion of the underlying policy rationales, and noting that the principle was still

As of 1 January 2018, amendments to the Standards Code became effective, which modify this proposition of law. See supra note 44, s 61.1(2).

Deputat, supra note 4 at para 27.

[1908] UKHL 701 [General Billposting].

Globex, supra note 4 at para 48. 
being followed by English courts, Alberta trial courts, and other Canadian trial courts, the Court concluded that the General Billposting principle remains good law in Alberta.

Justice Slatter, however, wrote a dissenting opinion, relying on the language of Justice Côté in Merrill Lynch that reaffirmed the employer's right to terminate the employment relationship without notice. While the majority concluded that the context of the language suggested against Justice Slatter's interpretation of it, they did not draw a particular distinction between whether pay in lieu of notice would have negated the breach and left the restrictive covenant intact.

Despite the ambiguity, the case is nonetheless important for two reasons. First, though not necessarily determinative of the point, the Mandatory Notice doctrine is far easier to reconcile with the General Billposting principle. If one regards the breach of contract as being the non-payment of a contractual debt at common law, there would be little guidance as to the point at which a dismissed employee could take the contract as having been breached. Moreover, if the contract has been duly terminated in accordance with its terms prior to the non-payment, then the repudiation analysis applied by the majority of the Court of Appeal in respect of an outstanding liquidated debt that survives the termination of the contract has no place.

Second, the case highlights the importance of understanding the implied contractual obligation. If the Contractual Option doctrine is correct, then an employer who wishes to preserve its rights under a non-competition or non-solicitation agreement would be able to simply provide appropriate pay in lieu of notice, thus rendering Globex distinguishable. On the other hand, if the Mandatory Notice doctrine is correct, then an employee dismissed on a not-for-cause basis without appropriate notice (barring contractual language authorizing such a dismissal) would automatically be relieved of obligations pursuant to restrictive covenants.

The schism at issue is not simply academic, but raises issues of predictability in given classes of cases.

\section{E. EXtra-Provincial Authorities}

Outside of Alberta, the Mandatory Notice doctrine is regarded as trite law.

The Ontario Court of Appeal, in Taylor, noted that "[p]roper notice of termination is an implied term of the contract of employment; payment in lieu of notice is not." ${ }^{\prime 61}$ Similarly, in Love, the Court found the following:

When an employer terminates an employee without notice, an implied term of the employee's contract of employment entitles the employer to do so by giving proper notice of termination, during which the employee will continue to work under the terms and conditions of his contract. Alternatively, as happened in this case, an employer can terminate an employee without cause, but without providing proper notice. This constitutes 
a wrongful dismissal, in breach of the employee's contract, and any payment by the employer in lieu of notice is an attempt at compensation for the breach. ${ }^{62}$

In Taggart v. Canada Life Assurance Co., the Ontario Court of Appeal noted the employee's "contractual right to work and to be paid his salary and receive benefits throughout the entire 24 month notice period." 63

Dunlop is routinely followed within British Columbia, including in John Iacobucci v. WIC Radio Ltd. ${ }^{64}$ and Gillies v. Goldman Sachs. ${ }^{65}$

Other appellate courts, too, have relied upon Dunlop for this proposition. See Cabott v. Urban Systems Ltd. ${ }^{66}$ and White v. Woolworth (F.W.) Co. ${ }^{67}$

At the Supreme Court of Canada, it is difficult to authoritatively pin down a position. As noted above, the Supreme Court has articulated the principle variously in ways that could be argued to support either doctrine. The case of IBM Canada Limited v. Waterman is particularly illustrative of this phenomenon. ${ }^{68}$

Mr. Waterman was dismissed without notice, but the dismissal triggered his full entitlements under a defined benefit pension plan. The legal question was whether the employer's liabilities for wrongful dismissal should be reduced by the amount of the pension received over the notice period.

Both the majority and the dissent (of Justice Rothstein and Chief Justice McLachlin) agreed that a straight application of the compensation principle would lean toward deducting the pension amount from the wrongful dismissal damages. However, the majority extended the "collateral benefit" doctrine to permit the double-recovery in this instance. ${ }^{69}$ The dissent saw no reason to do so. This was the full extent of their analytical difference, and both asserted that performance of the contract required actual notice.

The majority acknowledged that, "[h] ad IBM not breached the contract of employment and instead given him working notice, he would have received only his salary during that period and not his pension." 70

The dissent's analysis was similar: "First, I consider whether it is necessary to deduct the pension benefits Mr. Waterman received during the reasonable notice period in order to put

Love, supra note 2 at para 44.

2006 CanLII 53345 (Ont CA) at para 16 [Taggart].

$64 \quad 1999$ BCCA 753.

652001 BCCA 683.

2016 YKCA 4

67 (1996), 139 Nfld \& PEIR 324 (Nfld CA). In this pre-Sylvester case, the employer argued that the logic from Dunlop led, via the compensation principle, to a conclusion that an employee cannot recover wrongful dismissal damages in respect of a portion of the reasonable notice period in which he was unable to work due to disability. As the Newfoundland Court of Appeal noted, this argument is precisely the opposite of the result reached in Dunlop (and later in Sylvester), and the Newfoundland Court of Appeal did not appear to question the accuracy of the principle as set out in Dunlop.

2013 SCC 70 [Waterman].

Ibid at paras 85-98.

Ibid at para 33 [emphasis added]. 
him in the position he would have been in had the contract been performed - i.e. had he been given reasonable notice and worked through the end of the reasonable notice period." ${ }^{.71}$

These passages, especially considering the overall analysis in both the majority and the dissenting reasons, should be fatal to the Contractual Option doctrine. While the majority's disposition of the case is not entirely inconsistent with the Contractual Option doctrine, its analysis is.

However, the majority also used other language. The majority described, "IBM's obligation was to give Mr. Waterman reasonable notice of dismissal or pay in lieu of it." Then, when describing the result in Sylvester, the majority seems to have parenthetically endorsed the Contractual Option doctrine again: "There was clearly no causal link between the employer's failure to give reasonable notice of termination (or payment in lieu of notice) and the receipt of the disability benefits., ${ }^{, 73}$

Thus, despite the ratio in both the majority and dissenting reasons very clearly treating the hypothetical performance of the contract as requiring working notice specifically, some confusion on the point may be understandable.

\section{Practical Consequences}

Setting aside the theoretical incompatibility of the Contractual Option doctrine with application of the mitigation principle, as well as the tax implications of wrongful dismissal settlements and judgments, few cases turn on whether the breach of contract in wrongful dismissal cases occurred at the point of termination or at the point of non-payment. While the principles underlying calculation of "contractual pay in lieu of notice" are unclear, it is very clear in general that an employee dismissed without notice will be entitled to a quantum very similar to that which would be calculated in accordance with the compensation principle, and even the courts applying the Contractual Option doctrine largely follow that trend.

However, there are certain classes of cases where the issue must arise. In such cases, the schism raises troubling issues of uncertainty and can often lead to questionable results.

\section{A. Pension Benefits}

The question of an employee's entitlement to compensation for losses of pension benefits, while perhaps one of the most difficult heads of damages to properly quantify in wrongful dismissal litigation, has been one of the less controversial issues in this area. The leading case on the subject in Ontario is Taggart:

Assuming that the pension plans can be read as requiring active service as a prerequisite for the accrual of pension benefits, I find unpersuasive the argument that this precludes damages as compensation for lost

Ibid at para 117 [emphasis added].

Ibid at para 2.

Ibid at para 30. 
pension benefits. This argument, it seems to me, ignores the legal nature of the respondent's claim. The claim is not, as I have said, for the pension benefits themselves. Rather, it is for common law contract damages as compensation for the pension benefits the respondent would have earned had the appellant not breached the contract of employment. The respondent had the contractual right to work and to be paid his salary and receive benefits throughout the entire 24 month notice period. The appellant chose to terminate the respondent after two months and pay him damages rather than allow him to work through the remainder of the 22 month notice period. Had his contractual right not been breached, he would have earned his full pension. By terminating the respondent earlier, the appellant became liable to pay damages that "place the employee in the position that he or she would have been in had the contract been performed - the proper measure of

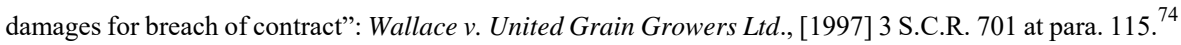

The underlying logic here, while well-grounded in the Supreme Court authority upon which it relies, is integrally premised on the Mandatory Notice doctrine. Whether the same conclusion would be reached under the Contractual Option doctrine is doubtful. It is unlikely that an implied contractual obligation to provide pay in lieu of notice would extend to indemnification for lost pension benefits.

The Alberta Court of Appeal came to a similar conclusion to the one in Taggart in 1986 (pre-Dunlop and long before Merrill Lynch) in Avtar Singh Athwal v. Edmonton (City). ${ }^{75}$ An employee was dismissed slightly more than a year before his pension vested. The trial judge found that he was entitled to a reasonable notice period of 13 months and awarded compensation for lost pension benefits of approximately $\$ 26,000$. The City appealed, arguing that the reasonable notice period was no longer than 12 months (which would have ended 2 weeks before the pension vesting date). The Court of Appeal upheld the award, not only by invoking the typical implied term of reasonable notice, but by further invoking other tests for implied terms, determining that the parties would not have intended the contract to be terminable by the employer "on the eve of vesting":

In the result, if the employee had been kept on but given 12 months' notice he would still have been in the employ of the City at a point where only two weeks remained until the vesting of the pension. The vesting of the pension would then be imminent, and the period of notice ought to be extended to permit the employee to remain until his pension vests. We therefore affirm the short extension made by the learned trial judge, which, of course, created the head of damages awarded. ${ }^{76}$

The Court of Appeal expressly disclaims the precedent value of this decision, but the internal logic soundly rejects the Contractual Option doctrine. Not only does the employer lack the right to terminate at any time without notice, but the employer lacks the right altogether to secure an effective termination date that falls just before a vesting date.

Otherwise, the question has not frequently arisen in Alberta. It is uncontroversial that pension contributions form part of an employer's liability during the reasonable notice 
period, without the requirement to prove a loss, ${ }^{77}$ but the impact of a provable loss beyond the value of the contributions does not appear to have been adjudicated since the emergence of the Contractual Option doctrine.

\section{B. Forfeiture Clauses}

A great deal of case law has arisen from contexts where employees have some form of variable compensation element, which is subject to a caveat - whether via a unilateral policy implemented by the employer or an express agreement as between the employer and employee - that any entitlement requires that the employee be "actively employed" as at a given vesting or payout date. This language is sometimes described as a "forfeiture clause."

Up until relatively recently, the law in Ontario appeared to largely respect the right of an employer to offer benefits to employees subject to a forfeiture clause and terminate those benefits immediately upon termination of employment. ${ }^{78}$

However, courts have routinely wrestled with the mechanism by which an employee is bound to a forfeiture clause. In Poole v. Whirlpool Corporation, the employer maintained a policy of paying bonuses only to those who were actively employed, but they had never brought this policy to the plaintiff's attention. ${ }^{79}$ The Court, concluding that notice of the clause was certainly necessary, cited Grace v. Reader's Digest Assn. (Canada) Ltd.:

\footnotetext{
The case law is clear that where there is a non-discretionary bonus and where the employer seeks to rely on a term requiring the employee to meet certain conditions such as being on the payroll as of a certain date, the employer must communicate that requirement to the employee. If the employer has failed to do so, then the employee is entitled to claim the bonus. ${ }^{80}$
}

Accordingly, Mr. Poole received not only the benefits that would have been paid out during the notice period, but also prorated benefits in respect of what have been "earned" but not paid during the notice period.

There are other considerations when enforcing a forfeiture clause. In a case where an employee's statutory minimum notice period encompassed the payout date for the bonus, the

Recently, Master Schlosser expressed concerns about this doctrine, suggesting that he would have required the plaintiffs to prove a loss were he not bound by precedent: see Eberle $v$ Sunhills Mining Limited Partnership, 2018 ABQB 389; Engelhardt v Sunhills Mining Limited Partnership, 2018 ABQB 383.

78 This general right was sometimes subject to a caveat that a bonus that was an integral part of the employee's overall compensation package could not be excluded in such a way. See Schumacher v Toronto-Dominion Bank (1997), 147 DLR (4th) 128 (Ont Ct J (Gen Div)). In general, however, the case law suggests that the "integral" nature of the bonus is generally going to be a precondition to any entitlement to the bonus in the first place, and that even entitlements to an integral bonus could be displaced by agreement. There are relatively few cases, however, where a bonus is found not to be "integral." 
requirement that she be "actively employed" could not be enforced to disentitle her to that payment. ${ }^{81}$

In Love, which is akin to the forfeiture clause cases, an employee held stock in the employer's company, but the Investment Agreement gave the employer a right to purchase the shares back when the plaintiff ceased to be an employee. The plaintiff, following his dismissal without notice, took the position that the repurchase value should be fixed at the end of the reasonable notice period, not the beginning. The Court rejected this position. When a contract is terminated without notice, it ends immediately, and the dismissed individual is no longer an employee, though he may be entitled to damages. Therefore, the share repurchase option was properly triggered immediately. The Court did not go on to consider, however, whether or not he may nonetheless be entitled to wrongful dismissal damages flowing from his lost entitlement to retain the shares through the reasonable notice period.

In Bernier v. Nygard International Partnership, however, the result was rather different. ${ }^{82}$ In that case, an employee whose contract entitled her to an annual bonus, provided that she was employed on 30 November, was dismissed in December 2012. She was, accordingly, paid her 2012 bonus, but with an 18-month notice period, her entitlement to compensation in respect of her 2013 bonus came into issue: "[ $\mathrm{t}$ ]he Defendant submits that the common law notice period is 13 months, while the Plaintiff submits that the period of reasonable notice at common law is more in the range of 18 months. Either way, the Plaintiff should have been given a period of notice that would have seen her actively employed on November 30 , 2013." 83

The Court awarded the bonus payable in 2013 on the basis that she would have been actively employed had she received the notice to which she was contractually entitled, and therefore this is a compensable loss flowing from the breach. "The Defendant cannot avoid the obligation to include the bonus that the Plaintiff would have been entitled to receive in 2013 had she been given proper notice of termination." 84 However, even with her notice period carrying through into mid-2014, the forfeiture clause had the effect of denying her any claim to a partial or pro-rated 2014 bonus. ${ }^{85}$

The Ontario Court of Appeal affirmed this decision in very brief reasons: "Had the plaintiff been given proper notice, she would have been employed as at November 30, 2013. The appellant cannot disentitle the plaintiff to damages for the loss of her bonus by reason of its own breach." 86

Sandhu $v$ Solutions 2 go Inc, 2012 ONSC 2073. Note that the law in Ontario is now reasonably clear that the voiding mechanism of the ESA is one that voids non-compliant terms ab initio, meaning that it is likely not necessary for a plaintiff to show that the "active employment" policy does diminish statutory entitlements on the facts of the case, so much as that the language itself is structured in such a way that it could diminish statutory entitlements. 2013 ONSC 4578 [Bernier].

Ibid at para 46 .

Ibid at para 47.

Ibid at para 48. This finding is an important distinction here, for reasons which will be discussed below. 2013 ONCA 780. 
Cases dealing specifically with stock options have been notoriously fickle in Ontario. In 1999, in Veer v. Dover Corporation (Canada), the Ontario Court of Appeal applied an analysis very similar to that later applied in Bernier. ${ }^{87}$ Even with language that provided that the employee's unexercised stock options would terminate at the termination of employment, whether "voluntary or involuntary," the Court nonetheless read the language - absent language to the contrary - as presuming that the termination would be lawful. ${ }^{88}$ Therefore, the employee's damages include any losses flowing from the loss of his stock options.

In Kieran v. Ingram Micro Inc., the result was essentially the opposite. ${ }^{89}$ The language of the plan unambiguously terminated the options as soon as Mr. Kieran ceased to be an employee, and he was bound by those terms. As in Love, the Court did not go on to examine whether or not the wrongful nature of the dismissal itself could nonetheless lead to a remedy for the premature loss of stock options.

The current leading case on forfeiture clauses in Ontario is Paquette v. TeraGo Networks Inc. ${ }^{90} \mathrm{Mr}$. Paquette was entitled to a bonus which, under the terms of the bonus plan, required that he be actively employed on the payout date. He was dismissed without notice in November 2014, and was awarded a reasonable notice period of 17 months. The question on appeal was whether or not his damages should include compensation in respect of the bonuses which would have been paid in February of 2015 and February of 2016.

The Court of Appeal answered in the affirmative. Extensively citing Taggart, the Court concluded that the question was not whether the employee was "actively employed" at the payout date, but whether, but for the breach of contract by the employer, he would have been:

First, the appellant's entitlement to bonus payments in the context of the wrongful dismissal action did not depend on whether he was notionally or in fact "actively employed" after his employment was terminated. The issue before the court was the determination of his damages, comprised of the compensation and benefits to which he would have been entitled but for the wrongful termination of his employment. Had the appellant been terminated within the 17 months' reasonable notice fixed by the motion judge, he would have been "actively employed" when the bonuses were paid. ${ }^{91}$

The Court of Appeal, accordingly, set out a two-part test for determining whether or not the loss of a bonus through the reasonable notice period is compensable. First, one must determine whether the bonus was "an integral part of the terminated employee's compensation." ${ }^{.92}$ Secondly, one must determine if there is "something in the bonus plan that would specifically remove the appellant's common law entitlement." ${ }^{.93}$ The question is whether "the wording of the plan unambiguously alters or removes the appellant's common law rights." 94

1999 CanLII 3008 (Ont CA) [Veer].

Ibid at para 11 .

2004 CanLII 4852 (Ont CA) [Kieran].

2016 ONCA 618 [Paquette].

Ibid at para 21 .

Ibid at para 30.

Ibid at para 31 .

Ibid. 
The employer in Paquette relied heavily upon Kieran. The Court of Appeal distinguished Kieran as being a "stock option case," but attempted to reconcile Kieran with Veer, by asserting that the language in Kieran was factually adequate to displace the employee's common law rights. ${ }^{95}$ Finally, in a striking piece of obiter, the Court suggests that the tests might be streamlined for these kinds of issues: "Without deciding whether the test that applies in stock option cases is the same as that applicable in bonus cases, I note the similarity between the approach I have set out above and that of Lang J.A., as well as the tests adopted in other stock option cases. $" 96$

The Ontario Court of Appeal has subsequently applied an analysis based in Taggart and Paquette in a stock option case, Bain v. UBS Securities Canada Inc. ${ }^{97}$ As such, the streamlining contemplated in Paquette is probably the current state of the law in that province.

Accordingly, Ontario has been moving toward a more restrictive interpretation of forfeiture clauses, as a direct application of the Mandatory Notice doctrine and its resulting first principles damages analysis.

In Alberta, the difference is manifest, as the Contractual Option cases almost exclusively deal with forfeiture clauses. While the Alberta Court of Appeal's conclusions in Merrill Lynch and Styles could be grounded in the fact that the employer's contractual obligations on termination were expressly limited in the first place, Carroll appears to be on all fours with Veer and, if Ontario's “stock option cases" are now streamlined with bonus and pension cases, with Bernier and Paquette as well.

The Alberta Court of Appeal wants to give effect to the intention of the parties. If the intention of the parties is that an employee dismissed without notice should not receive any compensation in respect of future bonuses or stock options, then the law should honour that intention and allow them to modify the employee's entitlements in such a way.

If pay in lieu is a creature of contract, then the parties can agree to modify the contents of this contractual entitlement. Thus, while the default position might parallel the compensation principle, signing a side agreement that excludes a compensation element from contractual pay in lieu of notice should be relatively straightforward.

Under a damages analysis, this is more difficult. Doctrines that allow a potential plaintiff to cede an entitlement to damages in advance - such as waiver or estoppel — require much more express language, such as what the Ontario Court of Appeal was looking for in Veer. ${ }^{98}$

However, given the variety of ways in which an employment relationship might be rendered something other than "active" — including voluntary resignation, termination for

Ibid at paras $38-45$.

Ibid at para 44.

2018 ONCA 190.

It is, of course, possible for the parties to contract to a formula or specified sum of liquidated damages, as in Bowes, but this requires contractual language sufficient to displace the implied term of reasonable notice altogether. 
cause, termination on notice, or a wide range of leaves of absence - it is less than obvious that the parties specifically intended or understood that a forfeiture clause would apply to a not-for-cause termination without notice. A court can easily give effect to the plain language of a forfeiture clause without assuming that it is intended to modify express or implied contractual termination obligations.

This was the result in Bernier. The Ontario Court of Appeal in fact enforced the language of the forfeiture clause, but only to the extent that it dealt with rights that would not have fully vested by the end of the reasonable notice period.

\section{Disability Claims}

Disability coverage for employees who are not presently employed has not traditionally been widely available in Canada's insurance market. The assumption has generally been that disability insurance would (and must) terminate immediately at the end of employment. ${ }^{99}$

However, in recent years a market has developed for "transitional" disability coverage following the Ontario case of Brito v. Canac Kitchens. ${ }^{100}$

The plaintiff was dismissed without notice and was diagnosed with laryngeal cancer during the reasonable notice period. He sued for the value of the disability claim to which he would have been entitled had he still been employed by Canac when his disability arose. Canac argued that he ought to have secured his own replacement coverage in mitigation of his loss of coverage. However, the late Justice Echlin rejected this argument. The onus to establish a failure to mitigate was upon the employer, but "[i]nsufficient evidence was led to show that comparable coverage would have been available."101 The employer was held liable for over $\$ 200,000$ in damages relating to the loss of disability coverage.

In the wake of Brito, transitional coverage has become more widely available in Ontario. While most insurers do not offer extended long-term disability coverage as a matter of course, many will consider extensions on a case-by-case basis, and there are a few insurers that offer transitional coverage as a stand-alone product. ${ }^{102}$

It is unclear whether the Alberta courts would come to the same conclusion as Justice Echlin. As the principles for quantifying "contractual" pay in lieu of notice are rather vague, one can only speculate as to how such an issue would be resolved. However, given the high cost and unavailability of continuing a disability benefits package through a notional notice period, it seems unlikely that principles of contract law would lead to a conclusion that the parties had impliedly agreed that the employer would continue such a benefit or indemnify

In Ontario and the Northwest Territories, where employment standards legislation requires continuation of such benefits through the statutory minimum notice period, insurance coverage will usually extend through that period. This is a unique feature to insurance plans in those jurisdictions. 2011 ONSC 1011 [Brito SC], rev'd on other grounds 2012 ONCA 61.

Brito SC, ibid at para 14.

In practice, it is not frequently purchased. It is an expensive item to include in a settlement and not one for which most employees will typically hold out or make other valuable concessions. However, in the event that a settlement with a full and final release is not reached during the statutory minimum notice period, employers are well-advised to consider purchasing transitional coverage on a unilateral basis. 
losses that flow from its termination. Unlike in Brito, where the general unavailability of the product worked against the employer as a result of the onus to establish failure to mitigate, the Contractual Option doctrine would present a disabled plaintiff with the unenviable challenge of arguing that it was an implied term of the contract that the employer would purchase an insurance product that may not actually be reasonably available on the market.

Similar challenges may arise in essentially any context where the employee expects some employment-related benefit that flows from a third party. Pension benefits, discussed above, are one possible example. Customer tips and gratuities are another. ${ }^{103}$ Again, given the lack of clarity as to the principles underlying the quantum of this contractual pay in lieu of notice, there is certainly a debate to be had as to whether (and when) it includes amounts that would not have originated with the employer.

\section{AnCILlary Claims and OVerlapping Torts}

While rare, there are certain types of cases where contractual breach is a threshold issue to establishing other claims. These are cases where the technical definition of "breach" becomes critically important.

Successful economic tort claims attached to wrongful dismissal actions are rare, but not unheard of. In Drouillard v. Cogeco Cable Inc., the plaintiff was a former Cogeco employee who was hired by a Cogeco contractor, Mastec. ${ }^{104}$ Cogeco made it clear to Mastec that it did not want the plaintiff working on its projects, and Mastec essentially withdrew its offer of employment as a result. On this basis, Cogeco was held liable for damages for inducing breach of contract.

Under the Contractual Option framework, it is unlikely that such a claim could ever succeed. If the employer can be said to have a contractual option to provide pay in lieu of notice, then even deliberate third-party actions to make it impossible for the employer to continue to employ an employee through the reasonable notice period would be insulated from tort liability by the existence of that option.

There are other types of cases, as well, where breach may be a threshold issue. In Ontario, section 46.1 of the Human Rights Code provides civil courts with the jurisdiction to award damages in respect of Code breaches, but does not allow an individual to commence an action solely based on Code breaches ${ }^{105}$ (this is an optimal formula for wrongful dismissal cases. In jurisdictions that lack such a provision, employees are put into the oft-difficult position of having to decide whether to pursue a breach of contract in court or a human rights violation in the applicable administrative process). While untested, it is plausible that a failure to establish a cause of action in contract, tort, or equity may deprive Ontario's courts of jurisdiction to award a remedy under human rights legislation. dismissed server is entitled to claim lost tips over the course of the notice period as wrongful dismissal damages, there is little reported case law on the question in Alberta. See Moyen v D D Investments Inc, 2005 ABPC 317. 
The definition of breach is critical to these types of cases, where breach triggers thresholds to certain types of damage claims or procedural options.

\section{E. Limitations}

The precise nature of the breach of contract in wrongful dismissal cases may have a significant impact on the point at which the limitations period starts running.

There are two Ontario cases where this issue has arisen directly, where employees dismissed on actual notice treated the limitations period as running from the effective termination date.

In Jones $v$. Friedman, the plaintiff was given a notice of termination on 12 December 1994, with an effective date of 31 January $1995 .{ }^{106}$ At the time, the applicable limitation period was six years, and the plaintiff commenced the action on 30 January 2001.

The Court of Appeal summed up the relevant principles concisely: "A limitation period commences when the cause of action arises. In a breach of contract, the cause of action arises when the contract was breached. For the purposes of a wrongful dismissal action, the employment contract is breached when the employer dismisses the employee without reasonable notice." $" 107$

Likewise, in Bailey v. Milo-Food \& Agricultural Infrastructure \& Services Inc., an employee dismissed on two years' actual notice brought an action seeking additional pay in lieu of notice, as well as statutory severance pay. ${ }^{108} \mathrm{He}$ commenced his action several months later, and the Court reaffirmed the proposition in Jones that "a cause of action for wrongful dismissal arises on the date of notice of termination." 109

In the event that one applied the Contractual Option doctrine, these results would likely be different. If the breach is the failure to pay, then that does not occur until the end of the period of working notice, which would suggest that the limitation period cannot begin until the period of working notice has elapsed.

Indeed, the opposite result was reached in the outlier case of Webster v. Almore Trading, which is one of the rare Ontario cases following the Contractual Option doctrine:

Wrongful dismissal, in my view, raises a particularly difficult issue in the limitation context since it is not a dismissal per se that is actionable but rather dismissal without reasonable notice or salary in lieu of such notice, that is actionable. Accordingly, the limitation period for an action for wrongful dismissal does not

2017 ONCA 1004 [Bailey], leave to appeal to SCC refused, 37958 (20 September 2018). While it is generally true that 24 months is a cap on reasonable notice periods, it is a "soft" cap which can be and is exceeded in certain cases. Moreover, statutory severance pay obligations under Ontario's ESA cannot be satisfied by actual notice (though, in a long-standing doctrine which appears to defy first principles, they are regarded as subsumed within "pay in lieu" of common law notice), and so there is little question that he would have been entitled to them but for the limitations issue.

Ibid at para 6 . 
necessarily run from the date of actual dismissal. It is activated when the cause of action is discovered - that is, the date that the terminated employee knew or ought to have known that he was discharged without cause and without notice or pay in lieu of notice and that a proceeding would be an appropriate way to get redress. 110

Alberta's Provincial Court recently followed Webster and declined to follow Jones or Bailey, in context of a summary judgment application in Barrie v. Quickwrap Canada Ltd. ${ }^{111}$ The plaintiff was dismissed on 3 or 4 June 2015, and commenced his action on 7 June 2017. However, while the plaintiff knew that he was dismissed without notice no later than 4 June, he contends that he did not know until several days later that the employer was alleging just cause or that he would not receive any pay in lieu of notice. Accordingly, the Court concluded that there was a triable issue pertaining to the limitations period.

One might further note that, under the Contractual Option doctrine, an action commenced before the end of the period of working notice would likely be premature, as the breach has not yet occurred. This creates a problem of uncertainty in Alberta. In a case such as Bailey, with a two-year notice period, bringing the action prior to the end of the notice period may be premature, while commencement of the action after the end of the working notice period may be statute-barred.

\section{CONCLUding COMMentaRy}

Justice Côté drew attention to the imprecision of language in wrongful dismissal contexts, and there is certainly truth to that.

The Contractual Option doctrine draws from precedents that broadly articulate management rights or the options available to employers wishing to dismiss an employee. In Wallace v. United Grain Growers Ltd., the Supreme Court spoke of "the mutual right of both employers and employees to terminate an employment contract at any time," and of the importance of the employer's "ability to determine the composition of their workforce."112

An employer has the "right" to determine the composition of the workforce, and is acting within management rights when terminating an employment relationship without notice and immediately escorting the employee off the premises. Were an employee to refuse to leave, he or she may be unlawfully trespassing.

Likewise, the majority in Wallace also asserted that an employer has "two options: either to require the employee to continue working for the duration of that period or to give the employee pay in lieu of notice." 113 This is advice that employers across the country doubtless receive from skilled employment lawyers every day.

But none of these propositions are inconsistent with the Mandatory Notice doctrine.

2010 ONSC 3854 at para 12 [Webster] [emphasis added].

2018 ABPC 205.

[1997] 3 SCR 701 at paras 75-76.

Ibid at para 65 . 
These employer rights are not rights under the employment contract, but are derivative of their proprietary rights in respect of the business itself, left intact despite contractual obligations to the contrary by the law of efficient breach. Most obligations in employment contracts are not of the type that will typically be enforced by way of specific performance. Accordingly, breaching the contract and taking upon itself liabilities for any damages flowing from such breach is indeed the "right" of any employer. To tell an employer that it may terminate an employment relationship on notice or provide pay in lieu of such notice is semantically equivalent to telling a party to a contract that it has the option of satisfying its contractual obligations or compensating the non-breaching party for any losses flowing from the breach.

The law in Canada has long recognized the virtues of efficient breach. While we might occasionally use morally loaded language to discuss breach of contract, the reality is that efficient breaches of contract are often a good commercial practice, which should be permitted and even encouraged. Indeed, the dissent in Waterman criticized the majority's conclusions on the basis that it discouraged efficient breach. ${ }^{14}$

Accordingly, neither this article, nor the Mandatory Notice doctrine generally, should be interpreted as infusing a termination without notice with a morally blameworthy connotation. It is widely understood and accepted that employers have legitimate business reasons to prefer that an employee not remain in the workplace; working notice is rare, and a dismissal without notice, while breaching the implied contractual obligation, is not something that without more - could ever attract an award of moral damages.

Yet conflating efficient breach with a contractual termination right creates significant problems in the framework, undermining certainty and predictability. This is especially true in a context such as wrongful dismissal law in Alberta, where the relative historical dearth of wrongful dismissal jurisprudence often requires courts to look to persuasive extraprovincial precedents. Such a deep philosophical schism regarding the contractual underpinnings of wrongful dismissal makes it difficult to evaluate whether trite law elsewhere will be interpreted in a consistent manner in Alberta. 